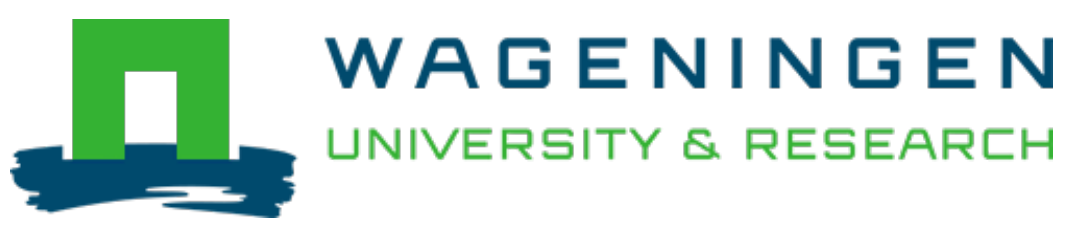

\title{
Ethno-food knowledge of baobab (Adansonia digitata L.) and characterisation of its traditional fermented novel foods from Benin
}

Proceedings of the Second International Symposium on Underutilized Plant Species: Crops for the Future Beyond Food Security, Kuala Lumpur, Malaysia, 27 June - 1 July 2011

Chadare, F.J.; Nout, M.J.R.; Boekel, M.A.J.S.

https://doi.org/10.17660/ActaHortic.2013.979.17

This publication is made publicly available in the institutional repository of Wageningen University and Research, under the terms of article $25 \mathrm{fa}$ of the Dutch Copyright Act, also known as the Amendment Taverne. This has been done with explicit consent by the author.

Article 25 fa states that the author of a short scientific work funded either wholly or partially by Dutch public funds is entitled to make that work publicly available for no consideration following a reasonable period of time after the work was first published, provided that clear reference is made to the source of the first publication of the work.

This publication is distributed under The Association of Universities in the Netherlands (VSNU) 'Article 25fa implementation' project. In this project research outputs of researchers employed by Dutch Universities that comply with the legal requirements of Article $25 \mathrm{fa}$ of the Dutch Copyright Act are distributed online and free of cost or other barriers in institutional repositories. Research outputs are distributed six months after their first online publication in the original published version and with proper attribution to the source of the original publication.

You are permitted to download and use the publication for personal purposes. All rights remain with the author(s) and / or copyright owner(s) of this work. Any use of the publication or parts of it other than authorised under article $25 \mathrm{fa}$ of the Dutch Copyright act is prohibited. Wageningen University \& Research and the author(s) of this publication shall not be held responsible or liable for any damages resulting from your (re)use of this publication.

For questions regarding the public availability of this publication please contact openscience.library@wur.nl 


\title{
Ethno-Food Knowledge of Baobab (Adansonia digitata L.) and Characterisation of Its Traditional Fermented Novel Foods from Benin
}

\author{
F.J. Chadare ${ }^{\mathrm{a}}$ and J.D. Hounhouigan \\ Faculty of Agronomic Sciences \\ University of Abomey-Calavi \\ Republic of Benin
}

\author{
M.J.R. Nout \\ Laboratory of Food Microbiology \\ Wageningen University \\ Wageningen \\ The Netherlands
}

\author{
M.A.J.S. van Boekel \\ Product Design and Quality Management Group \\ Wageningen University \\ Wageningen \\ The Netherlands
}

Keywords: baobab food uses, ethnic groups, Mutchayan, Dikouanyouri, Tayohounta, microorganisms groups, physico-chemical characterisation

\begin{abstract}
Adansonia digitata is a key economic tree used daily by local populations in Africa for food, medicines and cultural purposes. The aim of the study was to record the ethno-food knowledge on baobab processing and derived foods, and to further provide the properties of traditional fermented foods, for valorization purposes. Correspondence Analysis (CA) was used to link socio-cultural groups and food parameters. CA showed that the food uses of baobab parts vary from one ethnic group to another. The identified food categories were dough, gruel, drinks, sauces, snacks and flavouring agents. Some of the recorded products were fermented foods (spontaneous fermentation): Dikouanyouri (from seeds, $\mathrm{pH}=6.5$ ), Tayohounta (from kernels, $\mathrm{pH}=7$ ), and Mutchayan (from baobab pulp and sorghum, $\mathrm{pH}=4.2$ ). The predominant microorganisms in Dikouanyouri and Tayohounta were Bacillus spp. (8.5 and $9.5 \mathrm{log} \mathrm{cfu} / \mathrm{g})$ and lactic acid acteria (8.9 and $8.4 \mathrm{log} \mathrm{cfu} / \mathrm{g})$ respectively. In Mutchyayan, the predominant microorganisms were lactic acid bacteria $(8.1 \mathrm{log}$ cfu/g) and yeasts $(7.2 \mathrm{log} \mathrm{cfu} / \mathrm{g})$. From the outputs, strategies to improve processing techniques for production of more hygienic and safer baobab derived foods were proposed.
\end{abstract}

\section{INTRODUCTION}

Baobab (Adansonia digitata L.) is a widely distributed tree in many African countries and is used daily for food, as medicine and for other purposes (Wickens, 1982; Sidibe and Williams, 2002). Studies related to baobab species have provided data on the ecology, genetics, ethnobotanical aspects, and the chemical composition of its parts (Assogbadjo et al., 2006; Chadare et al., 2009; Diop et al., 2005). There is a recent awakening of interest and concern about the lack of documentation about traditional and indigenous food cultures which are important not only for their own sake, but for the legacy of food knowledge which they can confer on future generations, provided that they are not lost; hence, the value of special focus on African food cultures (Wahlqvist, 2007). However, the ethno-food knowledge of baobab is poorly documented and no study specifically addressed the characterization of traditional baobab foods. The present paper aimed at filling these gaps.

\section{METHODOLOGY}

Survey

First, a random check was performed on 198 users/processors offering their foods

a fchadare@gmail.com 
for sale on local markets to determine the proportion of users/processors of baobab food products. This proportion was used to compute the sample size $\mathrm{N}_{\mathrm{i}}$ of baobab processors to be interviewed, using the following formula:

$$
N_{i}=\frac{4 p i\left(1-p_{i}\right)}{d^{2}},(\text { Dagnelli, 1998) }
$$

where $N_{i}$ is the total number of users/processors to be surveyed for the study; $p_{i}$ is the proportion of baobab users/processors among the 198 randomly checked persons; $d$ is the expected error margin in the conclusion, which is fixed at 0.05 (Dagnelli, 1998). Multivariate analysis was used to link socio-cultural groups and baobab food uses.

\section{Microbiological Analyses}

Total aerobic mesophilic bacteria were enumerated on Nutrient Agar (Remel 454182, Bie and Berntsen, Rodovre, Denmark) $\left(37^{\circ} \mathrm{C}, 48 \mathrm{~h}\right)$. Bacterial spores (mainly Bacillus spp.) were enumerated on Nutrient Agar (Remel 454182, Bie and Berntsen, Rodovre, Denmark) $\left(37^{\circ} \mathrm{C}, 48 \mathrm{~h}\right)$, from a $10^{-1}$ dilution that had been heated for $10 \mathrm{~min}$ at $80^{\circ} \mathrm{C}$ to kill vegetative cells. Lactic acid bacteria were enumerated on de Man Rogosa and Sharpe Agar (MRSA, CM 361, Oxoid, Hampshire, England) containing 0.1\% (w/v) natamycin (Delvocid, Gist-Brocades, Delft, The Netherlands) after incubation at $30^{\circ} \mathrm{C}$ for 3-4 days. Colonies were confirmed by oxidase and catalase tests (Nout, 1991). Yeasts were counted after incubation at $25^{\circ} \mathrm{C}$ for $3-5$ days on a mixture -MYGP- of malt extract $(3 \mathrm{~g})$, yeast extract $(3 \mathrm{~g})$, glucose $(10 \mathrm{~g})$, peptone $(5 \mathrm{~g})$ and agar $(20 \mathrm{~g})$ supplemented with chloramphenicol and chlortetracycline (Jespersen et al., 1994).

\section{Physico-Chemical Analyses}

The $\mathrm{pH}$ and titratable acidity were measured immediately on the wet samples according to Nout et al. (1989). The dry matter, crude fat, and ash contents of the samples were determined, using AOAC methods 27.005, 27.006, and 27.009, respectively (AOAC, 1984). Protein contents were measured using the Dumas method (Jung, 2003). Free amino nitrogen was measured using formol titration (Han et al., 1999). Protein was converted and expressed as total nitrogen using the factor of 6.25 .

\section{RESULTS}

\section{Relationship between Final Food Uses and Socio-Cultural Groups}

Among the 15 ethnic groups investigated, some have similar uses of parts of the baobab tree, while others differ. The result of the correspondence analysis (CA) (Fig. 1a and $b$ ) performed on the final food uses and socio-cultural groups showed that the first three axes explained 55.2\% of the observed variation. Partial correlations and contribution of each of the considered modalities allow identification of the socio-cultural groups and the end uses that are the best represented on each axis. The projection of the different modalities in the axes system shows that the food uses of baobab parts are specific for the ethnic groups. Considering axis 1 (Fig. 1a), Berba, Wama, and Yom ethnic groups use baobab pulp to make Yewowi (P36 = product no.36), Tcho (P35) and Nanganfirou (P10) beverages. These ethnic groups, especially the women, process leaves into dry leaf (P5), dry leaf sauce (P22), and Touwoundou sauce (P28). Kernels are mainly used for Sarai sauce (P27). By contrast, Otamari and Tchocossi ethnic groups, especially adult and elderly people, use baobab pulp for making sour dough (P12), pulp drink (P3) and baobab syrup (P30). In these ethnic groups, seeds are used for making Matofaman (P17), Batokoue sauce (P19), and Dikouanyouri (P20) especially from the seeds that cannot be decorticated. Specifically, the Otamari people use baobab kernels mixed with locust beans for making Tayohounta type 2 (P34) and Mougoun-Mougoun (P7). With respect to axis 2 (Fig. 1a), the following ethnic groups: Datcha, Mahi (locality of Dassa), Otamari, 
Tchocossi, Comcombè, Dendi, and Lokpa have quite similar uses of some baobab parts; they use baobab fruits for making potash (P13). Apart from Datcha and Mahi, who use the whole fruit to make potash, all other ethnic groups use the empty fruit shell as raw material to make potash. In addition, the other ethnic groups (except Datcha and Mahi) produce baobab pulp (P16) from the fruits; they use pulp for making iced pulp beverage (P32) and they use leaves to produce and prepare dry leaf powder (P14), fresh leaves sauce (P21), and dry leaf powder sauce (P26). Specifically, Bariba use the pulp for Solani (P31) production; young people from the Dendi ethnic group produce Moukou-Moukou (P9) from pulp; the Dendi from Karimama locality produce Mougoundoro (P8) from whole seeds; Otamari, Tchocossi and Comcombè ethnic groups use seeds for making kernels (P1), kernels for making Tayohounta type 1 (P33) and roasted kernels (P2), and leaves to make Yatirankounti sauce (P29). Regarding axis 3 (Fig. 1b), it can be observed that the Gourmantche ethnic group produces roasted seed powder (P15); and the Nateri use leaves for Kouimkoundi sauce (P23); the Wama ethnic group uses pulp to make Norendoorou beverage (P11). Most ethnic groups (Berba, Brouba, Gourmantche, Dendi, Peulh, Otamari and Wama), produce seeds (P6) from the fruits, Moutopkei sauce (P24) from the seeds, gruel from the pulp and, with the exception of the Dendi, produce kernel sauce (P18) from the kernels.

Figure 2 shows the flow diagram for the processing of Dikouanyouri, Mutchayan and Tayohounta.

\section{Microbiological Characteristics of Mutchayan, Dikouanyouri and Tayohounta}

Table 1 shows that Dikouanyouri and Tayohounta contain very high levels of mesophilic aerobic bacteria (9.5 log $\mathrm{cfu} / \mathrm{g}$ ). Sporeformers (8.5 and $9.1 \mathrm{log} \mathrm{cfu} / \mathrm{g}$ respectively) and lactic acid bacteria (8.9 and $8.4 \mathrm{log}$ cfu/g respectively) were detected in large numbers. Especially for the sporeformers, this indicates that also high levels of vegetative cells of Bacillus spp. may be expected (i.e., the difference between the total count and the sporeformers and lactic acid bacteria). Possibly, other microorganisms will be present in these products; this will require further investigation. Mutchayan contained mainly lactic acid bacteria ( $7.6 \mathrm{log} \mathrm{cfu} / \mathrm{g})$ with a substantial amount of yeasts $(7.2 \mathrm{log}$ $\mathrm{cfu} / \mathrm{g}$ ) (Table 1). Counts in unfermented products were below the minimum level to be considered of relevance.

\section{Physico-Chemical Characteristics of Mutchayan, Dikouanyouri and Tayohounta: Impact of Fermentation}

Table 2 shows the characteristics of the 3 fermented products before and after fermentation. Important changes were noticed in Dikouanyouri and Tayohounta. For example, as a result of protein degradation, the ratio amino nitrogen/total nitrogen (i.e., an arbitrary index of protein cleavage) rose from $2.3 \%$ in the non-fermented product to $13.7 \%$ in the fermented Dikouanyouri and from $2.3 \%$ in the non fermented to $21.3 \%$ in the fermented Tayohounta.

\section{DISCUSSION}

\section{Ethno-Food Knowledge of Baobab Food Products}

The end uses of baobab parts are quite specific for the ethnic groups interviewed and differences were observed in the processing techniques for similar products among these ethnic groups. Over time, socio-cultural groups have accumulated a rich knowledge on the use of baobab but mostly with reference to their locality of origin. Moreover, ethnic groups are located in specific localities; the combination of an ethnic group and its locality may be a determinant for their food uses since food practices are usually cultural. According to Wahlqvist (2007), food culture is influenced most by the locality of its origin, which will have been one of food acquisition and processing by various means. Rivera et al. (2007), using hierarchical cluster analysis on gathered food plants in the mountains of Castilla-La Mancha in Spain, found that clusters of food plant species form 
culture-specific logical entities, which allow people to structure and manage their environment. Local populations have an outstanding knowledge of food uses of baobab.

\section{Properties of Baobab Fermented Foods}

The dominant microflora in Tayohounta and Dikouanyouri are bacteria, especially sporeforming bacilli (Bacillus spp.) and lactic acid bacteria. The predominance of Bacillus spp. was to be expected as it the case for most fermented seed products. In such seed products the fermentation is proteolytic; the bacilli are strong producers of proteolytic enzymes. Proteolysis leads to an increase of free amino acids such as lysine (Odunfa, 1985). Their predominance in these fermentations may be due to their ability to survive cooking and to initiate fermentation of both nitrogenous and carbohydrate products (Omafuvbe et al., 1999). This proteolysis is also expressed through protein degradation during the fermentation process. Though Mutchayan is primarily made from cereals, it is the only fermented cereal food enriched with baobab pulp juice. This addition increases the ascorbic acid content, which may play an important role as enhancer of mineral uptake (Hemalatha et al., 2005). The microflora of Mutchayan was dominated by lactic acid bacteria but the product contained also substantial amount of yeasts. This was to be expected in such a product due to its acidic $\mathrm{pH}$ of 4.2 , which is favourable for the development of such microorganisms. More detailed studies leading to development of starter cultures are necessary for production of safer products for a larger public.

\section{ACKNOWLEDGEMENTS}

The presentation of this paper has been supported by Crops for the Future through a grant provided by the UK Department for International Development (DFID) for the benefit of developing countries. The views expressed are not necessarily those of CFF or DFID. We are also thankful to local populations in Northern Benin for their cooperation.

\section{Literature Cited}

AOAC. 1984. Official Methods of Analysis of the Association of Official Analytical Chemists. $40^{\text {th }}$ edn. AOAC, Arlington, VA.

Assogbadjo, A.E., Kyndt, T., Sinsin, B., Gheysen, G. and Van Damme, P. 2006. Patterns of genetic and morphometric diversity in baobab (Adansonia digitata) populations across different climatic zones of Benin (west Africa). Annals of Botany 97:819-830.

Chadare, F.J., Linnemann, A.R., Hounhouigan, J.D., Nout, M.J.R. and van Boekel, M.A.J.S. 2009. Baobab food products: a review on their composition and nutritional value. Critical Reviews in Food Science and Nutrition 49:254-274.

Dagnelli, P. 1998. Statistiques théoriques et appliquées, vol. Tome 2.

Diop, A.G., Sakho, M., Dornier, M., Cisse, M. and Reynes, M. 2005. Le baobab africain (Adansonia digitata L.): principales caractéristiques et utilisations. Fruits 61:55-69.

Han, B.Z., Kiers, J.L. and Nout, M.J.R. 1999. Solid-substrate fermentation of soybeans with Rhizopus spp.: comparison of discontinuous rotation with stationary bed fermentation. J. Biosci. Bioeng. 88:205-209.

Hemalatha, S., Platel, K. and Srinivasan, K. 2005. Influence of food acidulants on bioaccessibility of zinc and iron from selected food grains. Molecular Nutrition and Food Research 49:950-956.

Jespersen, L., Halm, M., Kpodo, K. and Jakobsen, M. 1994. Significance of yeast and moulds occuring in maize dough fermentation for "kenkey" production. International Journal of Food Microbiology 24:239-248.

Jung, S. 2003. Comparison of Kjeldahl and Dumas methods for determining protein contents of soybean products. The Journal of the American Oil Chemists' Society 80:1169-1173.

Nout, M.J.R. 1991. Ecology of accelerated natural lactic fermentation of sorghum-based infant food formulas. International Journal of Food Microbiology 12:217-224.

Nout, M.J.R., Rombouts, F.M. and Havelaar, A. 1989. Effect of accelerated natural lactic 
fermentation of infant good ingredients on some pathogenic microorganisms. International Journal of Food Microbiology 8:351-361.

Odunfa, S.A. 1985. Biochemical changes during iru fermentation. Journal of food Technology 20:295-303.

Omafuvbe, B.O., Abiose, S.H. and Adaraloye, O.O. 1999. The production of 'Kpaye' - a fermented condiment from Prosopis africana (Guill and Perr) Taub. seeds. International Journal of Food Microbiology 51:183-186.

Rivera, D., Obon, C., Inocencio, C., Heinrich, M., Verde, A., Fajardo, J. and Palazon, A. 2007. Gathered food plants in the mountains of Castilla-La Mancha (Spain): ethnobotany and multivariate analysis. Economic Botany 61:269-289.

Sidibe, M. and Williams, J.T. 2002. Baobab: Adansonia digitata international center for underutilised crops, Southampton, UK.

Wahlqvist, M.L. 2007. Regional food culture and development. Asia Pacific Journal of Clinical Nutrition 16:2-7.

Wickens, G.E. 1982. The baobab - Africa's upside-down tree. Kew Bulletin 37:173-209.

\section{Tables}

Table 1. Microorganisms (log cfu/g) in "Mutchayan", "Dikouanyouri" and "Tayohounta".

\begin{tabular}{lccc}
\hline Microorganisms group & Mutchayan & Dikouanyouri & Tayohounta \\
\hline Total mesophilic aerobic bacteria (TMC) & $7.5 \pm 0.8 \mathrm{~b}$ & $9.5 \pm 0.6 \mathrm{a}$ & $9.5 \pm 0.6 \mathrm{a}$ \\
Total sporeformers (TS) & ND & $8.5 \pm 1.0 \mathrm{a}$ & $9.1 \pm 1.1 \mathrm{a}$ \\
Lactic acid bacteria (LAB) & $7.6 \pm 0.4 \mathrm{c}$ & $8.9 \pm 0.4 \mathrm{a}$ & $8.4 \pm 0.8 \mathrm{~b}$ \\
Yeasts (Y) & $7.2 \pm 0.6 \mathrm{a}$ & $5.5 \pm 0.5 \mathrm{~b}$ & $5.3 \pm 1.3 \mathrm{~b}$ \\
\hline
\end{tabular}

Values represent the mean scores $(\mathrm{n}=6$ samples and 2 replications of each \pm standard deviation).

ND: not detected.

For each parameter (each row), means with the same letter are not significantly different $(\mathrm{p}<0.05)$. 
Table 2. Effect of fermentation on the physico-chemical characteristics of "Mutchayan", "Dikouanyouri" and "Tayohounta".

\begin{tabular}{|c|c|c|c|c|c|c|}
\hline \multirow{2}{*}{ Parameters } & \multicolumn{2}{|c|}{ Dikouanyouri } & \multicolumn{2}{|c|}{ Tayohounta } & \multicolumn{2}{|c|}{ Mutchayan } \\
\hline & Unfermented & Fermented & Unfermented & Fermented & Unfermented & Fermented \\
\hline Dry matter $(\mathrm{g} / 100 \mathrm{~g})$ & $36.6 \pm 0.2 \mathrm{c}$ & $37.5 \pm 0.1 \mathrm{c}$ & $49.7 \pm 0.5 \mathrm{a}$ & $46.1 \pm 1.9 \mathrm{~b}$ & $22.2 \pm 0.3 \mathrm{~d}$ & $22.5 \pm 1.5 \mathrm{~d}$ \\
\hline Crude lipids (g/100 g dm) & $13.0 \pm 0.5 \mathrm{~d}$ & $17.2 \pm 1.06 \mathrm{c}$ & $36.9 \pm 0.9 \mathrm{a}$ & $42.5 \pm 0.6 b$ & $0.7 \pm 0.06 \mathrm{e}$ & $1.6 \pm 0.4 \mathrm{e}$ \\
\hline $\operatorname{Ash}(g / 100 \mathrm{~g} \mathrm{dm})$ & $4.7 \pm 0.2 b$ & $10.9 \pm 3.2 \mathrm{a}$ & $8.6 \pm 0.2 \mathrm{a}$ & $9.6 \pm 0.4 \mathrm{a}$ & $2.2 \pm 0.0 \mathrm{~b}$ & $2.2 \pm 0.4 \mathrm{~b}$ \\
\hline $\mathrm{pH}$ & $6.7 \pm 0.0 \mathrm{a}$ & $6.5 \pm 0.7 \mathrm{a}$ & $6.4 \pm 0.0 \mathrm{a}$ & $7.0 \pm 0.5 \mathrm{a}$ & $4.2 \pm 0.0 \mathrm{~b}$ & $4.2 \pm 0.3 b$ \\
\hline $\begin{array}{l}\text { Titratable acidity } \\
(\mathrm{mmol} \mathrm{NaOH} / 100 \mathrm{~g} \mathrm{dm})\end{array}$ & $6.9 \pm 0.2 \mathrm{~d}$ & $14.3 \pm 1.7 b$ & $11.6 \pm 01.7 \mathrm{c}$ & $17.5 \pm 2.8 b$ & $23.2 \pm 0.4 \mathrm{a}$ & $17.5 \pm 3.7 b$ \\
\hline $\begin{array}{l}\text { Total nitrogen } \\
(\mathrm{mmol} \mathrm{N} / 100 \mathrm{~g} \mathrm{dm})\end{array}$ & $342.5 \pm 17.2 b$ & $290.5 \pm 42.4 \mathrm{c}$ & $476.9 \pm 11.6 \mathrm{a}$ & $496.5 \pm 16.6 \mathrm{a}$ & $106.6 \pm 1.1 \mathrm{~d}$ & $120.2 \pm 6.9 \mathrm{~d}$ \\
\hline $\begin{array}{l}\text { Free amino nitrogen } \\
(\mathrm{mmol} \mathrm{AN} / 100 \mathrm{~g} \mathrm{dm})\end{array}$ & $7.9 \pm 0.5 \mathrm{c}$ & $39.7 \pm 5.0 \mathrm{~b}$ & $11.0 \pm 0.3 \mathrm{c}$ & $105.7 \pm 10.8 \mathrm{a}$ & $0.0 \pm 0.0 \mathrm{~d}$ & $0.00 \pm 0.0 \mathrm{~d}$ \\
\hline $\begin{array}{l}\text { Index of protein cleavage }= \\
\text { free mino nitrogen/total nitrogen }\end{array}$ & 2.3 & 13.7 & 2.3 & 21.3 & 0 & 0 \\
\hline
\end{tabular}

$(\%)$

Values represent the mean scores ( $\mathrm{n}=6$ samples and 2 replications of each \pm standard deviation). For each parameter (each row), means with the same letter are not significantly different $(\mathrm{p}<0.05)$ 


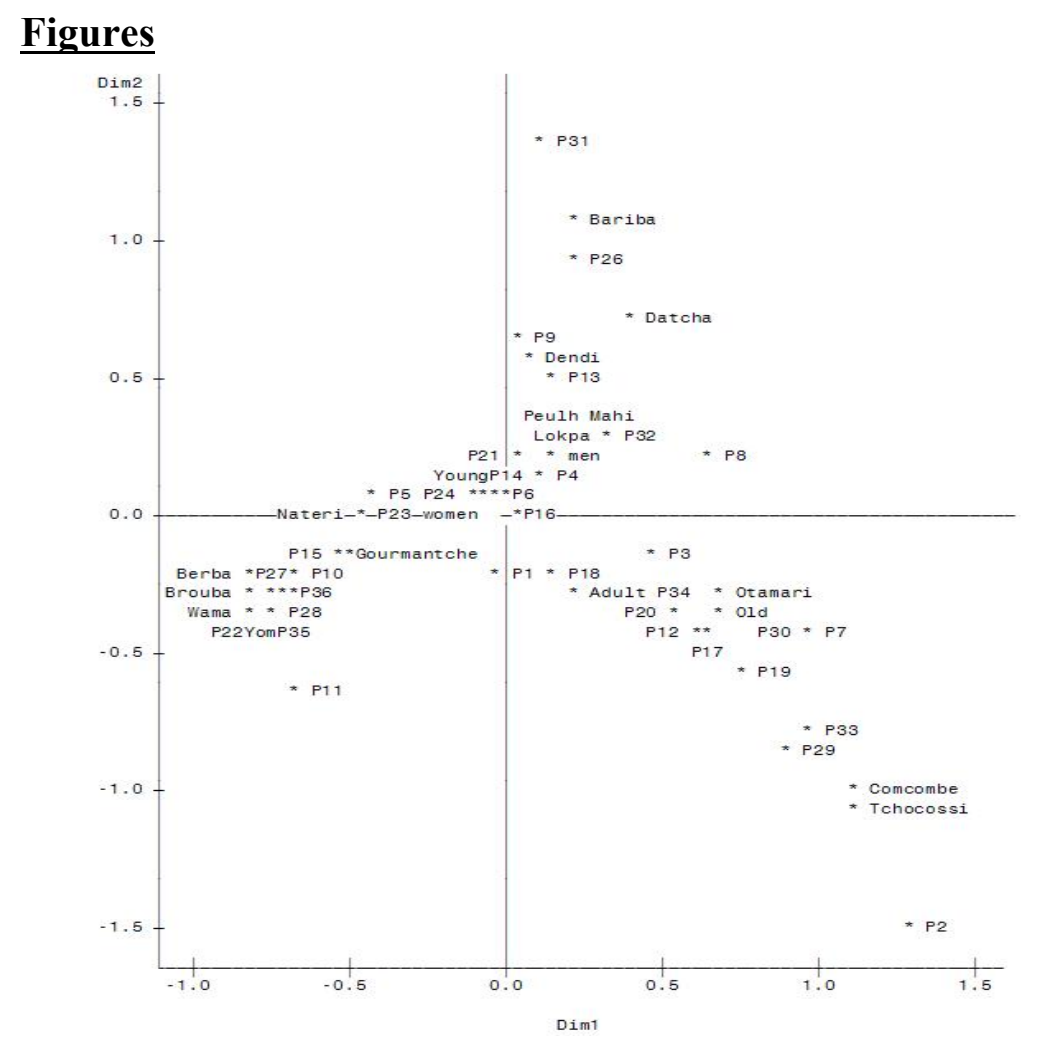

a

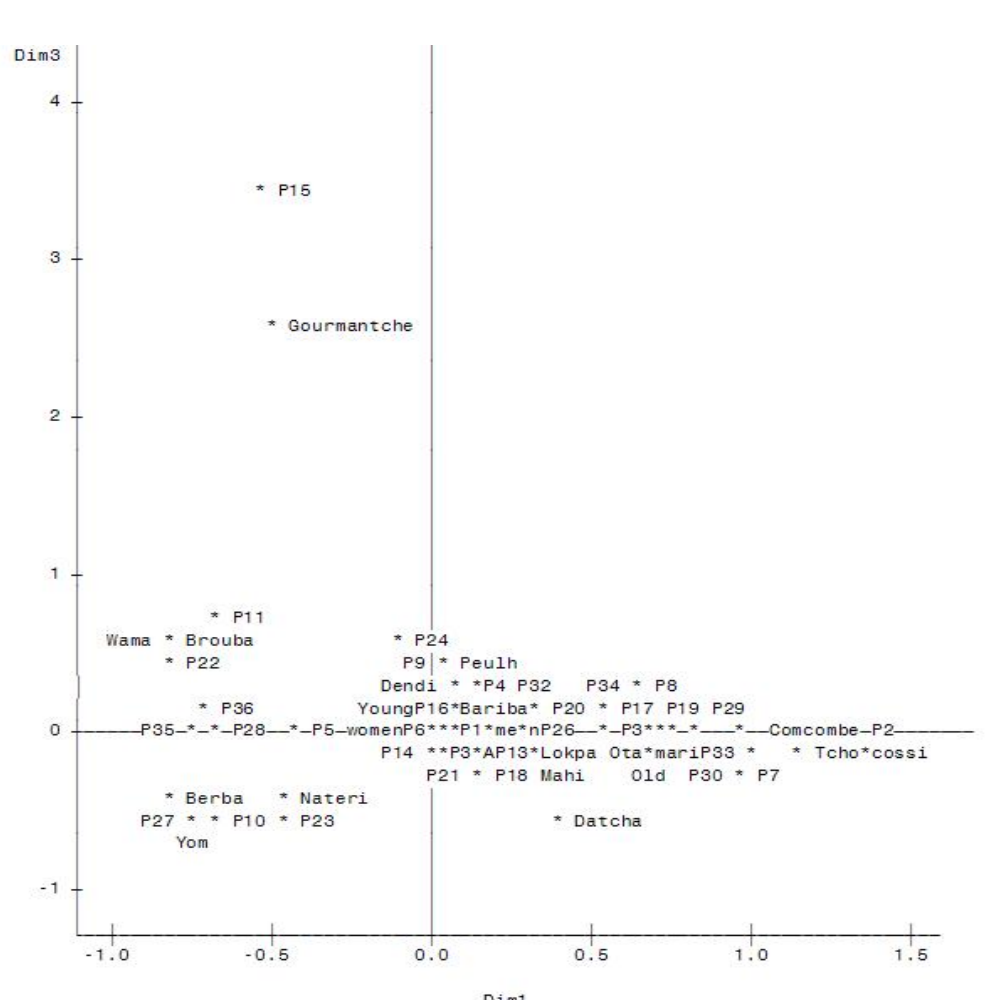

b

Fig. 1. a. Correspondence analysis to reveal linkages between baobab uses and socio-cultural groups on axes 1 and 2; b. correspondence analysis to reveal linkages between baobab uses and socio-cultural groups on axis 3. Legend: $\mathrm{P}=\mathrm{Product} ; \mathrm{P} 1=\mathrm{Kernels}$; $\mathrm{P} 2=$ roasted kernels; P3 = pulp drink; P4 = Gruel; P5 = dry leaf; P6 = seeds; P7 = Mougou-Mougou; P8 = Mougoundoro; P9 = Moukou-Moukou; P10 = Nanganfirou; P11 = Norendoorou; P12 = sour dough; P13 = potash; P14 = dry leaf powder; P15 = powder from roasted seeds; P16 = pulp; P17 = Matofaman sauce; P18 = kernels sauce; P19= Batokoue sauce; P20 = Dikouanyouri sauce; P21 = fresh leaves sauce; P22 = dry leaf sauce; P23 = Kouimkoundi sauce; P24 = Moutokpei sauce; P26 = leaf powder sauce; P27 = Sarai sauce; P28 = Touwoundou sauce; P29 = Yatirankounti sauce; P30 = baobab syrup; P31 = Solani; P32 = iced pulp beverage; P33 = Tayohounta type 1; P34 = Tayohounta type 2; P35 = Tcho; P36 =Yewowi. 


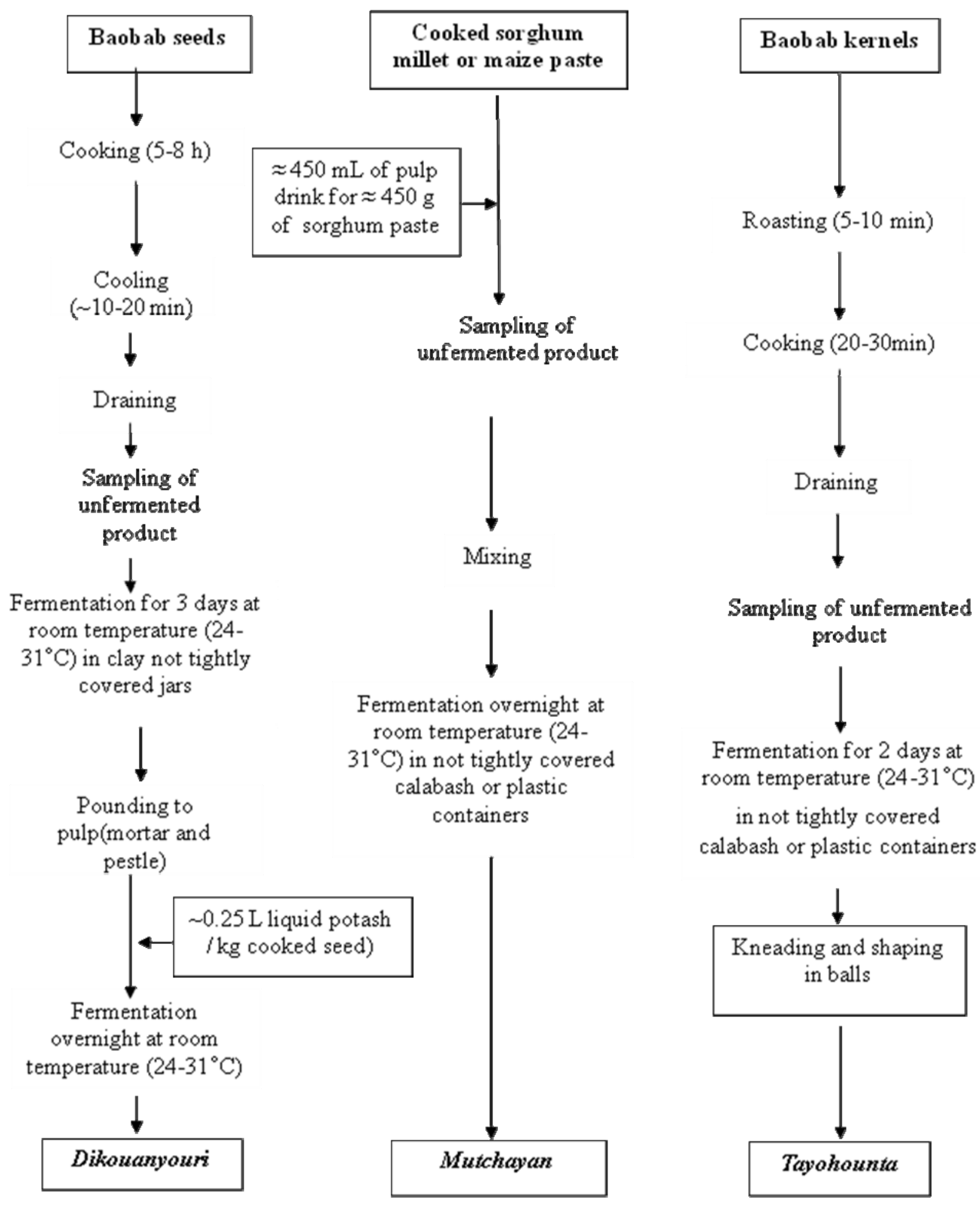

Fig. 2. Flow diagram for the processing of "Dikouanyouri", "Mutchayan" and "Tayohounta". 